\title{
Bringing Rare Books to Light: The State of the Profession
}

When the Association of Research Libraries (ARL) released the results of its 1998 survey of special collections, the backlog of unprocessed and uncataloged collections emerged as one of the most serious and daunting issues facing the profession. An increasingly enthusiastic professional discourse about the "hidden collections" problem, as it became known, has developed as a result. The ARL Special Collections Task Force, convened in 2001 and dissolved in 2006, focused on exposing hidden collections as a top agenda item, and produced the much-cited white paper, "Hidden Collections, Scholarly Barriers." This active discourse has also induced a flurry of articles and professional meetings discussing strategies for increasing cataloging and processing productivity in special collections and has even led to the creation of a major funding source for exposing hidden collections: the Council on Library and Information Resources "Cataloging Hidden Collections and Archives" grant, offered annually since 2008.

Hidden collections are not a new problem by any means. Most who work with special collections can share frustrating experiences related to inadequate access. Beyond the fundamental problem caused by hidden collections - that researchers who may be interested in the materials often have no way of knowing about them-many tangential issues arise from lack of access. Collections with limited access receive limited use, and collections that receive limited use are usually low priorities for preservation and digitization. As more institutions begin to focus on exciting new directions for special collections materials, such as large digital projects and increased incorporation into undergraduate curriculum, the lack of existing metadata for materials has become an even more acute problem, often reducing the potential value of materials simply because they are not adequately arranged and described.

In this article we consider whether this recent focus on an old problem has motivated special collections professionals to find innovative solutions in the specific area of rare books. The many recent articles on backlog projects have included very little information on whether there has been widespread creation and adoption 
of new strategies for addressing rare book backlogs. We present the results of a survey we distributed to rare book catalogers, intended to determine whether they have followed the hidden collections discourse, whether they have made any recent changes in cataloging practices and policies, and the nature of those changes.

We hoped that the survey might give us new ideas for increasing cataloging productivity at our institution, Southern Illinois University Carbondale. Like most other institutions with rare book collections, we have a rare book backlog. Since 2008, we have implemented a comprehensive approach for increasing rare book cataloging productivity without creating new positions. We have more than doubled our cataloging productivity through these measures, described below, but we still have a long way to go to make our entire backlog accessible.

It is worth noting that some of the survey respondents reported that they do not want to change their cataloging practices, for various reasons. Although this article assumes that exposing hidden collections is desirable, some in our profession would disagree with this focus for perfectly valid reasons, some of which are listed in the survey results below. In providing practical information about what we "can" do to increase cataloging productivity, we also hope to provide some perspective on whether we "should" do this. Every institution is different, and different collections within institutions require different levels of access. Balancing the desire for perfect description with the desire for maximum access has always been at the heart of rare book cataloging, and this article offers a glimpse at current thinking about this balance.

\section{Literature Review}

Recent efforts to combat the hidden collections problem were largely inspired by the white paper compiled by Barbara M. Jones in 2003, "Hidden Collections, Scholarly Barriers: Creating Access to Unprocessed Special Collections Materials in America’s Research Libraries." Jones identifies the main concerns with hidden collections, which include poor security, inadequate access for researchers, dependence on staff and institutional memory, and preservation. ${ }^{1}$ Perhaps most significant is the relationship between access and service. Without adequate access to materials, special collections' ability to provide good service to users is compromised. ${ }^{2}$

While some level of access to everything is preferable to comprehensive access to some materials and no access at all to others, this does involve trade-offs. Simply

1. Barbara M. Jones, "Hidden Collections, Scholarly Barriers: Creating Access to Unprocessed Special Collections Materials in America’s Research Libraries," RBM: A Journal of Rare Books, Manuscripts, \& Cultural Heritage 5, no. 2 (Fall 2004): 88-105

2. Ibid., 91,94 . 
streamlining the cataloging process across the board is not the solution, because different collections require different levels of access depending on the needs of the particular institution and its patrons, the resources available, and the nature of the material in question. ${ }^{3}$

Collaboration is a common theme in the white paper, both on a national level and locally. Jones encourages libraries to consider the effects of local decisions on the national community. While collection-level records can suffice locally, item-level records could be used by other institutions to enhance access to their collections as well. On the local level, access to hidden collections should be incorporated into the general library's access programs, such as the OPAC for catalog records and the library Web site for finding aids. ${ }^{4}$

A better balance is needed between resources used for purchasing and donations and those for processing and cataloging. Furthermore, while planning to eliminate the backlog, libraries must also develop strategies for keeping up with future acquisitions. Finally, Jones advocates a national collaborative approach to the hidden collections problem, as there are more backlog materials in special collections libraries than any one institution can effectively handle. A uniform set of guidelines and external funding for cataloging projects would be good first steps toward this end. ${ }^{5}$

These and other concepts have been picked up in the discussion of how best to address the hidden collections problem. In her "Hidden Collections: The Elephant in the Closet," Carol Mandel asserts that, while hidden collections are a national problem, ultimately the solution is local. Multiple approaches will be required to create sustainable and searchable Web access to currently hidden collections. ${ }^{6}$ She advocates teamwork within institutions to better integrate special collections into the general library organization, and between institutions to share resources. Strategic plans are needed to assess and address priorities, including what level of description is appropriate for each collection.

Stanley N. Katz addresses the hidden collections problem from the point of view of scholars and researchers. He describes having to rely on the institutional memory of librarians and archivists to find materials he would never have otherwise known about, even with a finding aid, and asks the library community to think of scholars and teachers as their primary user audience, rather than trying to do too much for too many. He also recommends streamlining cataloging, stating that good meta-

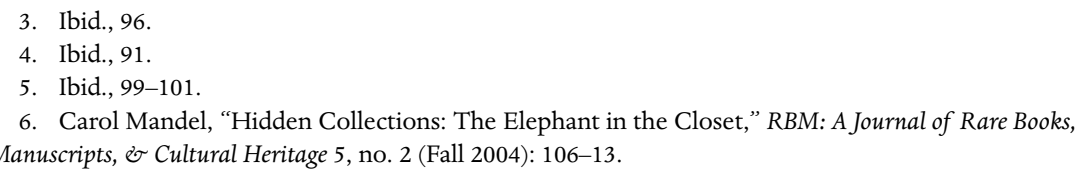


data (as opposed to perfect metadata) is sufficient for access, despite the trade-offs involved. ${ }^{7}$

Katz also responds to the hidden collections white paper and feels that, while national collaboration can be beneficial, it is more important to succeed on the local level. He argues that the main criterion for processing collections should be the realistic potential for use and that midlevel or partial descriptive options should be considered. ${ }^{8}$ He believes that the greatest failure of scholarly libraries is that they have not enlisted the active participation of scholars in planning, administration, and decision-making, while the scholarly community has also failed to engage libraries and librarians, not just on a local, individual level, but in high-level communication and coordination. ${ }^{9}$

Along with general theory and discussion of the hidden collections problem, several authors have reported on specific projects or approaches for addressing the problem. Beth M. Whittaker argues that, if special collections are what set libraries apart, libraries need to focus on technical services to make those collections accessible. The problem is not just backlogs and underprocessed collections, but the limitations to what can be done to provide intellectual access to special collections materials. ${ }^{10}$ She also argues that perfect records are unnecessary. The goal is to link users to materials, not have every possible note and indicator in every single record. Obstacles to providing even minimal records include increasing fragmentation among library communities because metadata functions are not integrated into existing technical services workflows. Because of this, special collections departments wind up managing their own metadata and may resist bringing in outsiders to discuss points of access.

Whittaker proposes several solutions to these problems. First, libraries should build on what they already have. If there is solid information on the print collections, a MARC field can be used for collection names so that curators don't have to maintain separate files. ${ }^{11}$ Digitizing is another possible solution, though Whittaker cautions against seeing digital images as the end product. Rather, images need to be delivered across the Web in a meaningful and searchable way, which requires good metadata. Collection-level cataloging may not be the ideal solution for all materials, but it can be a prominent tool in an access strategy. A large collection can

7. Stanley N. Katz, "Scholars and Teachers: Hidden Partners for Hidden Collections," RBM: A Journal of Rare Books, Manuscripts, \& Cultural Heritage 5, no. 2 (Fall 2004): 115-22.

8. Ibid., 117-18.

9. Ibid., 120 .

10. Beth M. Whittaker, “'Get It, Catalog It, Promote It': New Challenges to Providing Access to Special Collections,” RBM: A Journal of Rare Books, Manuscripts, \& Cultural Heritage 7, no. 2 (Fall 2006): 121-33.

11. Ibid., 127. 
even be split between different strategies, described at both the collection and item level depending on the materials and available resources. ${ }^{12}$

M. Winslow Lundy points out that, in general collections, even uncataloged items are given at least preliminary bibliographic records as part of the normal acquisitions workflow. Special collections are often excluded from this workflow and departments lack the extra staff to follow these procedures, but this kind of phased cataloging could provide a mechanism for keeping up with new acquisitions while still addressing the backlog. ${ }^{13}$ The downside to phased cataloging is that each item is handled multiple times. While many libraries do not have the luxury of phased cataloging, Lundy believes that bringing in the full record from OCLC at the point of order can help. She also advocates using students, even for more complex tasks, pointing out that libraries could take advantage of their subject or language expertise.

Lundy goes on to describe a project at the University of Colorado in Boulder in which graduate students, cataloging staff, and acquisitions staff created records for different collections at different levels. ${ }^{14}$ Other projects described in the literature include training graduate students to process collections in their area of interest at the Center for Primary Research and Training at UCLA, ${ }^{15}$ using public services staff for cataloging projects at Auburn University, ${ }^{16}$ and a library-faculty partnership at the University of Chicago that trained graduate students to work with and process primary source materials and used scholars' expertise to determine processing priorities and levels. ${ }^{17}$

General discussion in the literature about the hidden collections problem is helpful for informing libraries' decision-making process about their own hidden collections, and the specific projects reported prove the efficacy of much of the advice. However, these discussions and reports do little to indicate how widespread the application of these or other ideas actually are in the profession.

\section{Survey Methodology}

To gauge the reaction of the rare book cataloging profession to the hidden collections discourse, we issued a 19-question survey (see Appendix 2). The survey focused

12. Ibid., 128-31.

13. M. Winslow Lundy, "Providing Access to Uncataloged Special Collections with In-Process Records," Cataloging \& Classification Quarterly 45, no. 1 (2007): 39-58.

14. Ibid., 48

15. Victoria Steele, "Exposing Hidden Collections," College \& Research Libraries News 69, no. 6 (June 2008): 316-31.

16. Cecilia M. Schmitz, "Revealing Hidden Collections: The Temporary Cataloging Project at Auburn University Libraries,” Technical Services Quarterly 19, no. 1 (2001): 47-60.

17. Alice Schreyer, "University of Chicago Explores Library-Faculty Partnerships in Uncovering Hidden Collections,” ARL: A Bimonthly Report on Research Library Issues \& Actions (April 2007): 4-8. 
primarily on the size of rare book collections and backlogs at participants' institutions, whether participants follow the hidden collections discourse, and whether participants have changed their rare book cataloging practices in response to the hidden collections discourse. Participants were asked to describe any changes in detail.

We created a Web site for the survey and distributed the link to the EXLIBRIS-L and DCRM-L listservs. The first page of the survey invited responses from those "responsible for the creation and/or administration of rare book cataloging policies." The survey was open for three weeks, and we received 96 usable responses. We discarded incomplete responses if the participant did not click "submit" after answering some of the questions. We are aware that sending the survey to listservs and allowing respondents to select themselves may have created some response bias issues. In particular, those who are more interested in the hidden collections discourse may have been more likely to respond. However, we viewed listserv distribution as the best way to access our target population of rare book catalogers from different types of institutions.

We analyzed the data by performing a correlation analysis using Pearson's correlation coefficient. In our presentation of the results below, we focus on "highly significant" correlations, which had a $P$-value of less than 0.01 .

\section{Survey Results}

Rare book backlogs are nearly universal. Fully 97.8 percent of respondents reported a backlog at their institution. There is a positive correlation between institutions with larger collections of cataloged rare books and those with larger backlogs. There is also a positive correlation between ARL members, larger backlogs, and larger cataloged collections.

The survey asked three questions designed to determine whether the respondents follow the hidden collections discourse. More than two-thirds (68.9\%) of respondents were aware of the work of the ARL Task Force on Special Collections. A total of 61.5 percent had read the 2003 white paper "Hidden Collections, Scholarly Barriers," and nearly three-quarters $(72 \%)$ had read other professional literature or attended professional meetings about hidden collections. There are positive correlations between those who are aware of the ARL task force, those who have read the White Paper, and those who have read other professional literature. Unsurprisingly, there is a positive correlation between respondents from ARL institutions and those who are aware of the ARL task force.

More than half of the respondents (55.2\%) have considered changes to rare book cataloging policies and practices at their institutions as a result of the hidden col- 
lections discourse; nearly that many $(51.1 \%)$ have implemented changes. There is a positive correlation between those who considered changes and those who implemented them. ARL members and those who are aware of the ARL task force are more likely to have considered changes, while those who have read other professional literature about hidden collections are more likely to have implemented changes. Institutions with more cataloged volumes and larger backlogs are more likely to have implemented changes.

Reasons given for not considering changes to cataloging practices include the following: 1) a small or nonexistent backlog; 2) having a plan for addressing the backlog prior to the advent of the hidden collections discourse; 3) lack of interest in change because the institution is already doing all it can to address the backlog; 4) inability to change because of the special descriptive needs of rare books; 5) lack of cooperation from other invested parties; 6) lack of resources; and 7) institutional focus on archival resources, to the detriment of rare book collections. The same reasons were given for not implementing changes to address rare book backlogs. Some respondents used this answer field to note that the hidden collections discourse helped them explain the need for changes to their administrators. Reasons for having considered but not implemented changes include these: 1) lack of resources; 2) institutional lack of interest in special collections and rare books; and 3) having plans for currently unimplemented changes.

Participants were asked to describe recent attempts to address rare book backlogs. Limited-term projects were the most common method reported, with 49 percent of respondents describing a project. Close to half of respondents (44.8\%) described changes in formal rare book policies. More than a third (36.5\%) reported that resources had been reallocated to rare book cataloging from other areas of the department or library, but only 27.1 percent described the creation of new positions devoted to cataloging rare books. More than one in ten (11.5\%) described various other methods of addressing rare book backlogs. The correlation table shows that respondents were likely to describe several methods of addressing the backlog at their institution, or none at all.

Respondents described recent changes to formal cataloging policies, including: 1) greater acceptance of existing cataloging copy; 2) varying fullness of records and/ or implementation of Descriptive Cataloging of Rare Materials (Books) (DCRM[B]); 3) reduced processing, such as writing less information on flags; 4) altered cataloging priorities; 5) allowing catalogers for a general collection to catalog some rare materials; 6) allowing paraprofessionals to catalog rare materials; 7) use of "inventorylevel" records, with the goal of upgrading all to DCRM(B) when time allows; 8) use of collection-level records with some item-level access; 9) less supervisory review 
of new records; and 10) discontinuing the use of certain subject headings. One respondent noted that the hidden collections initiative has reduced the priority level of rare book cataloging at their institution, in favor of archival processing.

When asked to describe any recent projects designed to address rare book backlogs, some respondents described projects designed to address a portion of the backlog, while others described projects intended to eliminate the rare book back$\log$ entirely. Some respondents' institutions created temporary positions for back$\log$ projects, and some of these were grant funded. Some outsourced a portion of their cataloging to an agency. Several respondents described multiple projects for addressing backlogs. One institution had applied for several grants for backlog projects but had not received any. That respondent speculated that grant awards tend to go to larger institutions.

When asked to describe the reallocation of resources from other parts of the department or institution to rare book cataloging, most who responded stated that non-rare book catalogers have been assigned to part-time cataloging work. These noncatalogers included curators, archivists, catalogers for a general collection, paraprofessionals, staff freed from other projects due to budget cuts, and student workers. One respondent noted that reallocating staff to rare book cataloging requires professional catalogers to spend more time training and supervising. Several respondents described losing positions or other resources due to recent budget cuts.

Other recent changes in cataloging practices described include the following: 1) Rare Book School training for those who have been assigned to rare book cataloging responsibilities but have little experience; 2) use of newer equipment; 3 ) more training sessions; 4) a re-established relationship with the English Short Title Catalogue; 5) retrospective conversion of catalog card records to MARC records; 6) raised awareness of other descriptive standards, such as DACS; and 7) creating an endowment-funded position.

More than a quarter $(26.9 \%)$ of respondents had sought grant funding for methods of addressing rare book backlogs, and, of those, 70 percent were successful. There is a positive correlation between seeking and receiving grant funding.

Respondents were asked to quantify increases in rare book cataloging due to any of the changes they described. Several people documented significant increases. However, some described decreases in cataloging due to reduced staffing.

Nearly three-quarters of respondents $(71.7 \%)$ believe that their institution's efforts to address backlogs have been successful, and 65.2 percent believe that their institu- 
tion's efforts are sustainable. A total of 94.5 percent of respondents report that their institution has made efforts to increase access to non-rare book hidden collections, such as manuscript and other archival collections.

\section{Survey Results Conclusions}

Did the professional discourse on hidden collections affect the consideration and implementation of changes at participants' institutions? We found correlations between those who had read some literature about hidden collections and those who had implemented changes, and those who were aware of the ARL Task Force on Special Collections and those who had considered changes. However, the survey data suggest that institution size may have a stronger influence on the implementation of changes, as those with larger cataloged collection and larger backlogs were more likely to have done so (see table 1 in Appendix 1).

The correlations between those who were aware of the ARL Task Force on Special Collections, those who had read the 2003 white paper "Hidden Collections, Scholarly Barriers," and those who had read other literature or attended professional meetings regarding hidden collections suggest that some respondents are actively following the hidden collections discourse, while some may not be following it at all. Those with larger cataloged collections were more likely to have read the white paper and other literature, which may suggest that individuals from larger institutions are more likely to read such literature.

Respondents reported a variety of changes to rare book cataloging policies designed to reduce backlogs, and these changes can be divided into three categories: (1) acceptance of less than full records; (2) the use of staff members who had not previously been allowed to catalog rare books; and (3) a reduction in other technical services related to cataloging, such as writing information on flags. Numbers 1 and 2 in the above list are probably related, as copy cataloging and minimal-level record creation do not require the intensive training and extensive knowledge traditionally associated with rare book cataloging. These policy changes may have been among the most innovative backlog reduction methods described, as limited-term projects involving hiring one or more catalogers to work on specific collections have long been a standard method for addressing backlogs. These kinds of limitedterm projects, while important, do not create sustainable methods for reducing backlogs over the long term, especially at institutions that continue to actively develop rare book collections.

That more than half of respondents reported at least considering changes in cataloging policies and practices in response to the hidden collections discourse suggests that the focus on this topic has been successful in fostering change in the 
profession. The 45 percent of respondents who have not considered changes have a variety of reasons for not doing so. Those who believe they are unable to change cataloging practices due to lack of resources or lack of cooperation from administrators or other invested parties may find the results of this survey helpful in creating changes that require little or no additional resources and in discussing the importance of this issue with other stakeholders. Those who chose not to consider changes either were satisfied with the current state of the institutional backlog and methods for addressing it or believed that changes in cataloging practices would create unacceptable compromises due to the unique descriptive needs of rare books. The latter is a significant concern. Patrons who use rare books are often serious scholars, some of whom may travel to institutions to use collections. Sufficient metadata is important to help these researchers make decisions about which materials will provide them with the information they need for their projects. However, we believe that "sufficient metadata" is a changing target and that some books can be adequately described using minimal-level records with certain copyspecific notes. Of course, "adequate" is not "ideal," but in some cases it is necessary to accept "good enough" records to make steady progress on growing backlogs. In our own experience, described below, we spent time considering the metadata needs for each of our backlogged collections, some of which continue to receive full-level DCRM(B) records created by a professional rare book cataloger.

The data do not support one respondent's suggestion that larger institutions have an advantage in the grant-awarding process, as there is no statistical correlation between collection size or ARL status and grant funding. The conclusion that larger institutions are more likely to have implemented changes may reflect higher levels of existing resources rather than more grant funding. The data do suggest that those considering applying for grants should do so, as the majority of applicants for grant funding received it.

While some respondents reported that the hidden collections initiative had caused rare book cataloging productivity to decrease as institutions shifted focus onto archival processing, some described the opposite phenomenon. When rare book and archival collections are administered as one "special collections" department, they must share limited resources, which makes addressing backlogs all the more difficult.

Recent budget cuts at some institutions have had a negative impact on rare book cataloging productivity. Although backlog projects involving new positions or resources reallocated to rare book cataloging may be out of reach for many institutions, many of the changes intended to expedite cataloging described by the survey respondents could be implemented anywhere. Some of these changes seem quite 
small, such as reducing the amount of information written on flags or discontinuing certain subject headings. However, streamlining workflows in this way can produce a noticeable increase in productivity over time. Some larger policy changes, such as greater acceptance of existing cataloging copy and more flexibility in using DCRM(B) and full-level records, can increase productivity even more. Although these tactics may not work for every institution or collection, they do not require significant additional resources. Respondents who reported that their institutions had implemented changes intended to address rare book backlogs usually described more than one kind of change. This suggests that some institutions are taking a comprehensive approach to streamlining rare book cataloging (see table 2 in Appendix 1).

\section{Local Case Study}

Southern Illinois University Carbondale has been no exception to the hidden collections problem, with both our archival and rare book collections needing a vast amount of processing and cataloging. In 2008, we estimated that our rare book collections had 43,498 cataloged titles and approximately 38,500 uncataloged titles. Addressing these hidden collections was further complicated by the fact that uncataloged titles were interfiled on the shelves with cataloged ones, with no way to tell the difference. This situation was made possible by an antiquated filing system in which books were shelved by collection, followed by main entry. Idiosyncrasies in how this system was applied, the presence of subcollections, and poor shelfreading made this system all but unusable, and staff found it impossible to reliably pull books requested by patrons.

One of our first tasks was to address this problem. We began a renumbering project, in which every book in the collection was assigned a six-digit consecutive number. We decided to use this system rather than a classification scheme like Library of Congress so that students could work on the project with minimal training. We also streamlined our flag labeling workflow, preprinting the flags with shelf marks to eliminate the laborious process of printing separate labels and matching them to the flags.

As the books are numbered, any uncataloged books are given to the rare book librarian, who creates a provisional record with author, title, publication information, and collection name and assigns the books a backlog number. These backlog books are shelved separately from the cataloged books and will be fully cataloged when time permits.

In addition to the interfiled uncataloged books, entire collections had never been cataloged. The Director of Special Collections, Rare Book Librarian, and Special 
Collections Cataloger meet on an annual basis to determine cataloging priorities for these uncataloged collections and to assess progress made over the previous year. The Early Printed Book Collection has been identified as our top priority, given the age, rarity, and value of many of the titles. These books are cataloged by the Special Collections Cataloger and are given full-level records following DCRM(B).

$\operatorname{DCRM}(\mathrm{B})$ has also informed our decisions about collections that do not require full-level cataloging. The introduction to $\operatorname{DCRM}(\mathrm{B})$ addresses precataloging decisions, encouraging careful consideration of the treatment needed for each item or collection of items, and pointing out that there may be circumstances in which AACR2, minimal-level, or collection-level records might be more appropriate for the material in hand. ${ }^{18}$ We considered the pros and cons of each of these options. For some materials, it was clearly more efficient to apply AACR2 rules rather than the detailed transcription dictated by DCRM(B), and we felt the potential loss of title-page information was acceptable. While minimal-level cataloging does not provide in-depth subject analysis, it does allow for quicker completion of records and allows us to provide at least some access to more materials. We have not yet applied collection-level records to any of our print collections; but we would consider doing so if it seemed appropriate for any of our collections, particularly as a temporary measure until such time as the materials in the collection could be given item-level records.

Collections we identified that do not require full-level cataloging include several philosophy-related collections of late 19th- and early 20th-century titles. For these collections, we have hired a half-time graduate assistant with a philosophy background. He does minimal-level AACR2 copy-cataloging for these materials, adding copy-specific information as appropriate. Items requiring original records are either passed to the Special Collections Cataloger or will be given provisional records and added to the backlog. In the nine months he has worked for us, he has cataloged 2,979 titles. Although this graduate assistant had no prior experience working with rare materials, he quickly grasped the nature of the materials and their potential research value, which aided his understanding of appropriate description. Although we would certainly consider hiring a nonhumanities graduate student for this work, it could require additional training and explanation of the use of special collections materials. We also had a backlog of recent acquisitions, mostly secondary literature related to our collections. A staff member in Special Collections was trained to do minimal-level copy-cataloging for these materials, resulting in 903 cataloged titles in 10 months.

18. Descriptive Cataloging of Rare Materials (Books) (Washington, D.C.: Cataloging Distribution Service, Library of Congress, 2007), 21. 
We have determined various cataloging levels for all of our collections. Some will require full-level DCRM(B) records once the Early Printed Book Collection is cataloged, while others will be good candidates for minimal-level work by graduate assistants or staff. Transfers from the general collection receive no extra cataloging but are simply assigned a new call number and then shelved. Our policy gives us the flexibility to make different decisions for specific items in hand, but the overall system has introduced much more efficiency into our cataloging.

Finally, to keep the backlog from getting out of hand, new acquisitions are moved to the front of the Special Collections Cataloger's queue. We do not have a large enough acquisitions budget to make this occasional interruption a problem; and since we are trying to collect in areas of interest to faculty on campus, this is a valuable service for our patrons as well.

Our goal is to have at least accession-level records for all of the books we own. Through these methods we have cataloged 6,600 books in the last two and a half years, bringing our uncataloged estimate down to 31,900 books. Progress is slow but steady and efficient. We are investigating external funding opportunities to create more cataloging positions, which would dramatically increase our productivity.

Increased cataloging productivity has already increased the use of our collections; and, although we have not collected any statistics, we know that many of the recently cataloged books have circulated in the reading room. Aside from cataloging, outreach to the campus community has been a recent focus of the Special Collections Research Center. We have discussed our cataloging projects with some faculty on campus, and we have received very positive feedback about the increased visibility of our collections, particularly the early printed books. However, increased cataloging productivity also has its drawbacks. In particular, it has increased other technical service needs for the rare book collections, such as shelving and applying security markings and mylar wrappers to books. In the past, most of these tasks were performed by the Rare Book Librarian with occasional assistance from a departmental student worker. The increasing number of books moving through the cataloging workflow has required us to increase the number of student worker hours devoted to shelving and processing rare books. This places a strain on the special collections department, as the budget for students is limited. So far, this situation has been manageable, but we may have gone as far as we can to increase cataloging productivity without also increasing the number of people involved in other technical services.

\section{Conclusion}

Our survey data make clear that the hidden collections discourse has had an impact on the profession. Many active professionals are currently implementing most of 
the solutions proposed in "Hidden Collections, Scholarly Barriers" and other recent literature. Many institutions have also made small local changes to technical services, such as writing less information on flags or discontinuing the use of certain subject headings. One suggestion repeatedly made in the literature was for national collaboration. None of the survey respondents described any such collaboration at their own institutions. It may be that, as Carol Mandel suggested, all hidden collections solutions are local and unique to each institution. However, collaborative digitization, exhibition, and collection development projects and programs are becoming more popular throughout the field. At this writing, the upcoming 51st Rare Books and Manuscripts Section (RBMS) Preconference for 2010 is titled "Join, or Die: Collaboration in Special Collections.” As rare book professionals begin to focus more on interinstitutional collaboration, they will have an opportunity to consider how cataloging can be approached from a collaborative perspective.

Several survey respondents reported that administrators are unwilling to consider changes to cataloging practices. Others reported that the recent focus on hidden collections has helped them explain the problem to administrators. This kind of resistance can be an obstacle to any change in established practices and policies. It may be helpful, in discussing hidden collections with administrators or other stakeholders, to cite the increasing body of literature on dealing with this national problem on a local level and to point out that many other institutions have successfully made small, low-cost changes. One potential area of collaboration, which may also help overcome resistance to change, is to develop support for backlog projects offered by state and regional consortia. Although this would not necessarily involve collaborative cataloging, it would help define the hidden collections problem to those who don't actively follow literature on rare book cataloging, and it could provide smaller institutions with guidance from the larger institutions in their consortia and more opportunities for grant-funded projects.

Another reason for resistance to change is that some who work with rare books believe that cataloging practices cannot be streamlined due to the descriptive needs of the materials. In our experience, this is certainly true for certain books and collections. In our approach, we continue to create full-level records for unique and highly valuable items. However, like many institutions, we have large 19th- and 20th-century collections. By creating policies for different types of collections that allow for minimal-level cataloging (with appropriate added notes and headings for certain items) and using paraprofessionals and graduate assistants for this type of cataloging, we have created more time for our professional cataloger to focus on creating full-level records for our most valuable books. In doing so, we have created access to a significant portion of our 19th- and 20th-century materials, and we have been able to catalog more of our highest value books at the same time. This 
approach relies on an understanding of the individual nature of each of our books and collections and, thus, could not work for every institution. However, we believe that many could benefit from considering whether increased flexibility in cataloging policies and practices could significantly increase access without significantly decreasing the quality of catalog records from a user's perspective. We believe we have developed a solution for our institution that meets this description.

While our data confirm that most institutions with rare book collections also have rare book backlogs, much progress is being made in developing practices to responsibly increase productivity. It seems that many rare book professionals have responded locally to a national call to action on this problem, and it is encouraging to see the great variety of strategies being implemented. Much can still be done to find solutions for small institutions, as well as those losing funding for rare book cataloging. Interinstitutional collaboration may eventually provide solutions for such institutions. In the meantime, the changes described herein by survey respondents may assist others as they continue to evaluate, change, and develop their own rare book cataloging policies and practices.

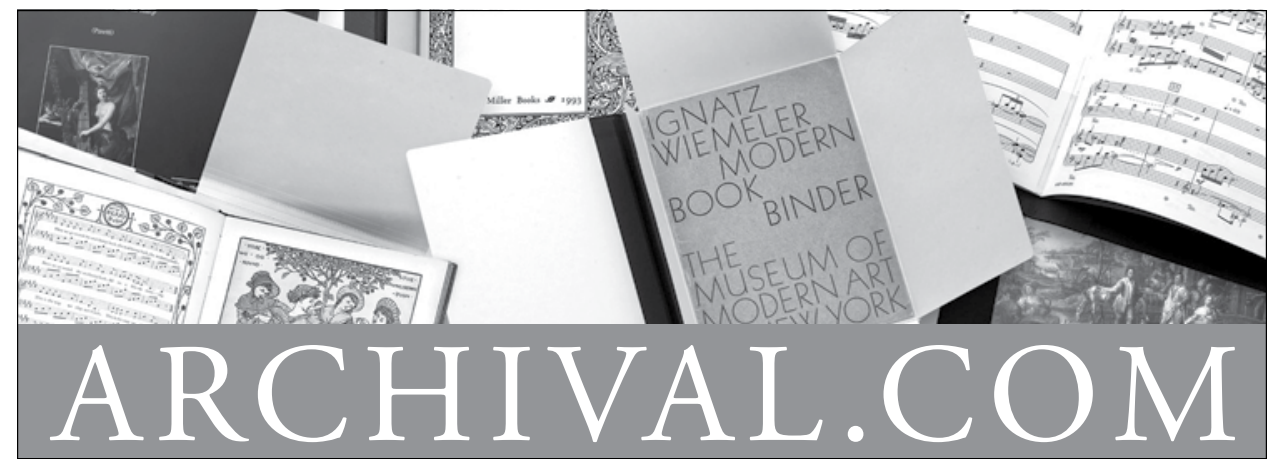

\section{INNOVATIVE SOLUTIONS FOR PRESERVATION}

Call for a complete catalog

Pamphlet Binders

Music Binders

Archival Folders

Manuscript Folders

Hinge Board Covers

Academy Folders

Newspaper/Map Folders

Bound Four Flap

Enclosures

Archival Binders
Polypropylene Sheet \& Photo Protectors Archival Boards Adhesives Bookkeeper Century Boxes

Conservation Cloths Non-Glare Polypropylene Book Covers

CoLibri Book Cover System
ARCHIVAL PRODUCTS

P.O. Box 1413

Des Moines, Iowa 50306-1413

Phone: 800.526.5640

Fax: 888.220.2397

E-mail: custserv@archival.com Web: archival.com 


\section{Appendix 1: Tables}

We analyzed all of our data using Pearson's correlation coefficient to uncover statistically significant patterns. Table 1 below displays the correlation strengths of factors influencing whether institutions have considered or implemented changes to rare book cataloging practices (see survey questions 4 through 9 and 11 in Appendix 2). All of the correlations described in the table are positive. Table 2 displays the correlations between positive responses to the series of questions about methods for backlog reduction (see survey question 13, parts A through E, in Appendix 2). The information here is particularly striking, as it indicates that most respondents who have used at least one of the methods listed have also used others. Notably, there are perfect correlations between those who described changes in cataloging policies, as well as "other" changes, and those who described limited-term projects, as well as "other" changes.

\begin{tabular}{|c|c|c|c|c|c|}
\hline & $\begin{array}{l}\text { Aware of } \\
\text { the Work } \\
\text { of the ARL } \\
\text { Task Force } \\
\text { on Special } \\
\text { Collections }\end{array}$ & $\begin{array}{l}\text { Read the } \\
2003 \text { White } \\
\text { Paper "Hidden } \\
\text { Collections, } \\
\text { Scholarly } \\
\text { Barriers" }\end{array}$ & $\begin{array}{l}\text { Read Other } \\
\text { Literature } \\
\text { or Attended } \\
\text { Meetings } \\
\text { Addressing This } \\
\text { Topic }\end{array}$ & $\begin{array}{l}\text { Larger } \\
\text { Backlog }\end{array}$ & $\begin{array}{l}\text { Larger } \\
\text { Cataloged } \\
\text { Collection }\end{array}$ \\
\hline $\begin{array}{l}\text { Considered } \\
\text { Changes }\end{array}$ & $\begin{array}{l}\text { Highly } \\
\text { significant } \\
\text { correlation }\end{array}$ & No correlation & No correlation & $\begin{array}{l}\text { No } \\
\text { correlation }\end{array}$ & $\begin{array}{l}\text { No } \\
\text { correlation }\end{array}$ \\
\hline $\begin{array}{l}\text { Implemented } \\
\text { Changes }\end{array}$ & No correlation & $\begin{array}{l}\text { Significant } \\
\text { correlation }\end{array}$ & $\begin{array}{l}\text { Highly } \\
\text { significant } \\
\text { correlation }\end{array}$ & $\begin{array}{l}\text { Highly } \\
\text { significant } \\
\text { correlation }\end{array}$ & $\begin{array}{l}\text { Highly } \\
\text { significant } \\
\text { correlation }\end{array}$ \\
\hline
\end{tabular}

\begin{tabular}{|c|c|c|c|c|c|}
\hline & $\begin{array}{l}\text { Changes in } \\
\text { Policies }\end{array}$ & $\begin{array}{l}\text { Limited-term } \\
\text { Projects }\end{array}$ & $\begin{array}{l}\text { Reallocation of } \\
\text { Resources }\end{array}$ & $\begin{array}{l}\text { Creation of } \\
\text { New Positions }\end{array}$ & Other \\
\hline $\begin{array}{l}\text { Changes in } \\
\text { Policies }\end{array}$ & $\begin{array}{l}\text { Highly significant } \\
\text { correlation }\end{array}$ & $\begin{array}{l}\text { Highly significant } \\
\text { correlation }\end{array}$ & $\begin{array}{l}\text { Highly significant } \\
\text { correlation }\end{array}$ & $\begin{array}{l}\text { Perfect } \\
\text { correlation }\end{array}$ & \\
\hline $\begin{array}{l}\text { Limited-term } \\
\text { Projects }\end{array}$ & $\begin{array}{l}\text { Highly significant } \\
\text { correlation }\end{array}$ & & $\begin{array}{l}\text { Highly significant } \\
\text { correlation }\end{array}$ & $\begin{array}{l}\text { Highly } \\
\text { significant } \\
\text { correlation }\end{array}$ & $\begin{array}{l}\text { Perfect } \\
\text { correlation }\end{array}$ \\
\hline $\begin{array}{l}\text { Reallocation } \\
\text { of Resources }\end{array}$ & $\begin{array}{l}\text { Highly significant } \\
\text { correlation }\end{array}$ & $\begin{array}{l}\text { Highly significant } \\
\text { correlation }\end{array}$ & & $\begin{array}{l}\text { Highly } \\
\text { significant } \\
\text { correlation }\end{array}$ & $\begin{array}{l}\text { Highly } \\
\text { significant } \\
\text { correlation }\end{array}$ \\
\hline $\begin{array}{l}\text { Creation of } \\
\text { New Positions }\end{array}$ & $\begin{array}{l}\text { Highly significant } \\
\text { correlation }\end{array}$ & $\begin{array}{l}\text { Highly significant } \\
\text { correlation }\end{array}$ & $\begin{array}{l}\text { Highly significant } \\
\text { correlation }\end{array}$ & & $\begin{array}{l}\text { Significant } \\
\text { correlation }\end{array}$ \\
\hline Other & $\begin{array}{l}\text { Perfect } \\
\text { correlation }\end{array}$ & $\begin{array}{l}\text { Perfect } \\
\text { correlation }\end{array}$ & $\begin{array}{l}\text { Highly significant } \\
\text { correlation }\end{array}$ & $\begin{array}{l}\text { Significant } \\
\text { correlation }\end{array}$ & \\
\hline
\end{tabular}




\section{Appendix 2: Survey Questions}

1. What is your job title?

2. Is your institution a member of the Association of Research Libraries?

3. Does your institution have a rare book backlog?

4. What is the estimated number of volumes in the backlog? Choose one of the following answers.
$\square$ Less than 1,000
口 $1,000-5,000$
口 $5,000-10,000$
口 10,000-25,000
口 More than 25,000

5. What is the estimated number of cataloged volumes in your institution's rare book collections? Choose one of the following answers.
Less than 10,000
口 10,000-50,000
口 50,000-100,000
口 100,000-500,000
口 More than 500,000

6. Are you aware of the work of the Association of Research Libraries Task Force on Special Collections?

7. Have you read the 2003 White Paper "Hidden Collections, Scholarly Barriers: Creating Access to Unprocessed Special Collections Materials in North America's Research Libraries," compiled by Barbara M. Jones?

8. Have you read other professional literature or attended any professional meetings that addressed the "hidden collections" problem?

9. Has the recent attention given to the "hidden collections" problem within the special collections field caused you to consider changing rare book cataloging policies or practices at your institution?

10. If not, why not?

11. Has your institution implemented any changes in rare book cataloging practices or procedures in response to the emphasis on the "hidden collections" problem?

12. If not, why not?

13. Please describe, in detail, any of the following changes in rare book cataloging practices or procedures that your institution has made:
A. Changes in formal rare book cataloging policies
B. Limited-term projects designed to address a portion of the backlog
C. Reallocation of resources from other areas of the department or library to cataloging
D. Creation of new positions devoted to cataloging rare books
E. Other 
14. Have you sought grant funding for any of the above changes?

15. If yes, were you successful?

16. Do you believe that your institution's attempts to address the rare book back$\log$ have been successful?

17. If possible, please provide quantitative data about any increases in rare book cataloging due to any changes in policies or procedures.

18. Do you believe that your institution's attempts to address the rare book backlog are sustainable?

19. Has your institution made any efforts to increase access to nonrare books in hidden collections (manuscripts, archives, and the like)?

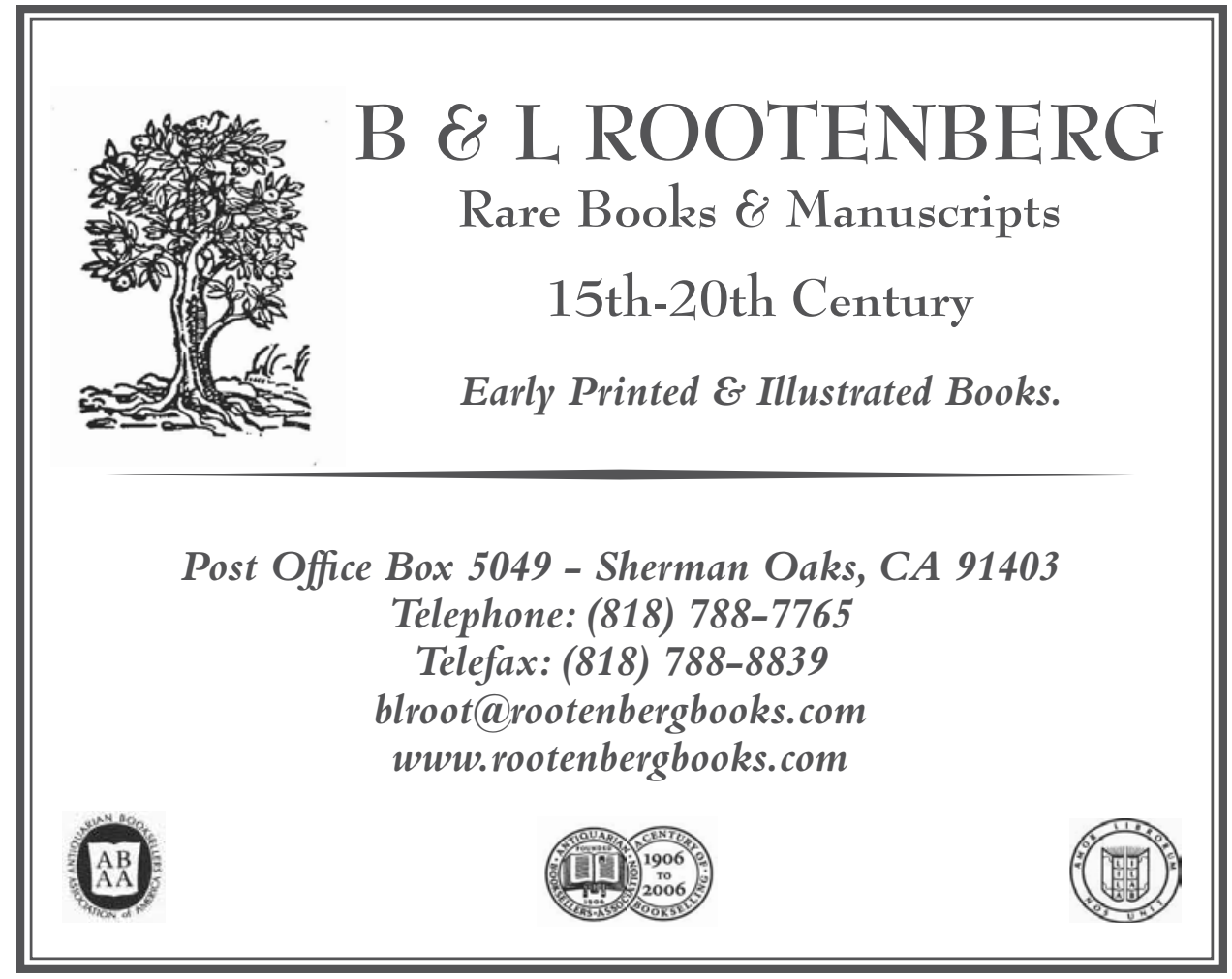

